These fellowships, which are awarded by a committee from the Bell Tolephone Laboratories, are designed to stimulate and assist research in the physical sciences by those who have recently received. doctorates or are about to receive them. The stipend is 4,000 dollars to the recipient and 1,500 dollars to the institution at which the research is carried out.

\section{Colonial Service : Recent Appointments}

THE following appointments have recently been made in the Colonial Service: J. L. Congdon (agricultural officer, Aden), director of agriculture, Aden ; R. A. Silverlock (agricultural survey officer, Gold Coast), agricultural officer, Gold Coast; G. M. Stockley (director of geological survey, Tanganyika), director of geological survey, British Guiana; J. H. Hinds (senior agricultural officer, Gold Coast), pasture research officer, Northern Rhodesia; E. A. Lewis (deputy director, East African Tsetse and Trypanosomiasis Research and Reclamation Organization), director of tho Organization; M. B. Noel-Buxton (fisheries officer, Gold Coast), senior fisheries officer, Gold Coast; D. MeCallum (education officer, Kenya), meteorologist, East Africa High Commission; L. Piening, plant pathologist, Department of Agriculture, Gold Coast ; A. M. M. Rees, agricultural economist, Northern Rhodesia; J. P. Scott, agricultural officer, Sierra Leone; T. E. Tomlinson, scientific officer, Sierra Leone; A. W. Peece, geologist, Uganda ; L. R. Boulger, pathologist, Nigeria ; B. W. H. Stronach, provincial tsetse officer, Tanganyika; Miss R. V. Suter, microbiologist, Microbiological Research Institute, Trinidad; J. W. Wholey, assistant conservator of forests, Nigeria.

\section{Announcements}

H.M. The QueEn has been graciously pleased to grant Her Royal Patronage to the Institution of Gas Engineers.

THE Hinchley Medal of the British Association of Chemists has been awarded to Dr. Herbert Levinstein, a trustee and past-president of the Association. The presentation will take place in the West Hall of the Royal Society of Medicine, 1 Wimpole Street, London, W.1, on February 27, at 6.30 p.m., and Dr. Levinstein will speak on "Our Changing Chemical Industries : an Appraisement". Prior to the presentation, there will be a brief opening ceremony at the now headquarters of the Association, at Hinchley House, 14 Harley Street, W.1.

DR. W. C. J. Ross has been appointed to the readership in chemistry tenable at the Institute of Cancer Research (Royal Cancer Hospital), University of London.

AN Easter vacation school in relaxation methods will be held in the Imperial College of Science and Technology, London, during April 9-23. The course will be on the lines of those of previous years and will cover the numerical solution of linear algebraic equations, framework problems, Laplace's and Poisson's equations, the biharmonic equation, eigen-value problems, the heat-conduction equation, threedimensional relaxation, etc. Lectures will be given in the mornings, and during the afternoons the instruction will consist of solving examples under supervision. The fee for the course is $\mathfrak{1 0} 0$. Further information can be obtained from D. N. de G. Allen, Imperial College, London, S.W.7.

A sUMmer school in analytical chemistry, organized by the Royal Institute of Chemistry and the Society of Public Analysts and Other Analytical Chemists and open only to members of these two bodies, will be held in the Royal College of Science and the Royal School of Mines, South Kensington, London, S.W.7, during September 6-12. The course will be divided into three parts, dealing with organic, metallurgical and biochemical analysis, respectively, and there will be one evening meeting on the need for statistical methods in analytical chemistry. The fee for the course is $£ 13$ ( $£ 3$ for the lectures only of any one part) ; hostel accommodation can be reserved. The course is limited to fifty persons. Further particulars can be obtained from G. Murfitt, at Metals and Methods, Ltd., Bacon Works, Langloy, near Slough, Bucks.

The eighteenth Cold Spring Harbor symposium on quantitative biology will be held during June 5-11, the general subject of the meetings being "Viruses". Emphasis will be on discussion of the quantitative aspects of virus research, particularly research with bacterial viruses, and the following problems will be discussed: virus in the vegetative state and its maturation, pro-virus, transition from pro-virus to vegetative virus, transition from the infective to the vegetative state, structure of viruses, biochemical studies of virus infections, host-controlled variations of viruses, and viruses in tissue culture. Further information can be obtained from the Biological Laboratory, Cold Spring Harbor, New York.

As in former years, a courso in tropical hygiene for laymen will be held by the Ross Institute of Tropical Hygiene (forming part of the London School of Hygiene and Tropical Medicine) during July 20-24. The course is for workers in the tropics holding, for example, administrative or executivo posts, whose responsibilities entail the health and welfare of others. Morning sessions will be devoted to malaria and its control, and in the afternoons other tropical diseases and problems such as hookworm, bilharzia, nutrition, housing and sanitation, and protection against heat will be dealt with. There is no fee for the course. Further information can be obtained from the Organizing Secretary, Ross Institute of Tropical Hygiene, Keppel Street (Gower Street), Loridon, W.C.I.

THE Institution of British Agricultural Engineers is offering a scholarship for students who experience financial difficulty in completing their studies during the academic year 1953-54 for the final examination of the National Diploma in Agricultural Engineering. The scholarship, which was given last year by the publishers of Farm Mechanization, is tenable at one of the colleges approved by the examination board of the Institution, and preference will be given to candidates with engineering qualifications. Application forms (to be completed by May 15) and further particulars can be obtained from the Secretary of the Institution of British Agricultural Engineers, 24 Portland Place, London, W.1.

Cambridge University Press announces that a list of errata so far discovered in the first edition of "The New Flora of the British Isles" by Clapham, Tutin and Warburg is now available. As most users of "The Flora" will want to transfer the necessary corrections to their copies of the book, the errata slip is being inserted loose in all remaining stock. Booksellers who wish to put the errata slip in their own stock copies, or to supply it to customers who have already bought the book, may have copies free of charge from the Cambridge University Press, Bentley House, 200 Euston Road, London, N.W.1. 